\title{
BLOOD CARBONIC ANHYDRASE ACTIVITY-A POSSIBLE ROLE \\ IN THE PRODUCTION OF ACID-BASE IMBALANCE IN \\ CHILDREN AND INFANTS*
}

\author{
A. R. BOUTROS, F.F.A.R.C.S., † AND V. R. WOODFORD, PH.D. +
}

THE ENZYME CARBONIC ANHYDRASE ${ }^{1}$ is a small zinc-containing protein of molecular weight about 31,000 . It is widely distributed in the tissues of the animal kingdom as well as in the leaves of green plants. In man $^{2}$ it exists in the red blood corpuscles, renal tubular cells, gastric mucosa, pancreas, eye, salivary glands, sweat glands, and central nervous system.

The only known role of carbonic anhydrase is to catalyse the reversible hydration of carbon dioxide. Thus in aqueous solution $\mathrm{CO}_{2}$ reacts reversibly with water to yield carbonic acid which in turn dissociates to bicarbonate and hydrogen ions:

$$
\text { (a) } \mathrm{CO}_{2}+\mathrm{H}_{2} \mathrm{O} \rightleftharpoons \mathrm{H}_{2} \mathrm{CO}_{3}, \quad \text { (b) } \mathrm{H}_{2} \mathrm{CO}_{3} \rightleftharpoons \mathrm{H}^{+}+\mathrm{HCO}_{3}^{-} \text {. }
$$

Reaction $(a)$ is relatively slower and if allowed to proceed uncatalysed, it will require 200 seconds to come within 10 per cent of equilibrium at $38^{\circ} \mathrm{C}$. Reaction $(b)$, on the other hand, is very fast and equilibrium is almost instantaneous. It is in catalysing reaction $(a)$ that carbonic anhydrase exerts its sole effect.

As this paper is concerned mainly with the role of carbonic anhydrase in the regulation of the blood $\mathrm{pH}$, a more detailed discussion of the factors involved in the above reactions will be germane to this work.

Carbon dioxide, resulting from the various metabolic processes in the tissues, is transported by the blood in one of several forms: carbamino compounds, bicarbonate, carbonic acid, and dissolved carbon dioxide. The carbonic acid-bicarbonate buffer system is one of the important regulators of blood $\mathrm{pH}$. The pH-buffer relationship for the bicarbonate system as expressed by the HendersonHasselbalch equation:

$$
\mathrm{pH}=\mathrm{p} K_{\mathbf{s}}+\log \frac{\left(\mathrm{HCO}_{3}^{-}\right)}{\left(\mathrm{H}_{\mathrm{HCO}}\right)}
$$

is inadequate to explain the efficacy of this buffer pair in the blood. At the normal blood $\mathrm{pH}$ of 7.4 , the ratio of $\left(\mathrm{HCO}_{3}\right)$ to $\left(\mathrm{H}_{2} \mathrm{CO}_{3}\right)$ is about $20: 1$. As is well known, the buffer efficiency becomes negligible if the ratio exceeds $10: 1$ unless there are means of increasing the buffer capacity. The ready availability

"This work was supported by grants from the Medical Research Council (No. MA-1135), and the Dean's Fund, College of Medicine, University of Saskatchewan.

fFrom the Department of Anaesthesia. University of Saskatchewan, and the University Hospital, Saskatoon, Saskatchewan. Present address. Department of Anesthesia, State University of Iowa, Iowa City, Iowa, U.S.A.

$\ddagger$ From the Department of Biochemistry, University of Saskatchew an; Saskatoon, Saskatchewan. 
of dissolved carbon dioxide and the presence of carbonic anhydrase in the erythrocytes provide these means. It has been shown ${ }^{3}$ that at equilibrium the molar ratio of dissolved carbon dioxide to carbonic acid is $809: 1$. The carbonic anhydrase, by catalysing the hydration of part of the dissolved $\mathrm{CO}_{2}$ to form $\mathrm{H}_{2} \mathrm{CO}_{3}$ in alkalosis, or the breakdown of the $\mathrm{H}_{2} \mathrm{CO}_{3}$ to $\mathrm{CO}_{2}$ and water in acidosis, is of great assistance in promoting the efficiency of this buffer system. It is thus clear that without the reservoir of dissolved carbon dioxide, the efficiency of the carbonic acid-bicarbonate system at the $\mathrm{pH}$ of the blood would be extremely poor. ${ }^{2}$

\section{Clinical and Physiological Considerations}

One of the intriguing features of open-heart surgery in children was the frequent occurrence of a noticeable degree of acidosis in the immediate postoperative period as soon as spontaneous respiration was allowed to start. This was reported upon in detail by Dobell, Gutelius, and Murphy. ${ }^{4}$ Data collected by these workers showed that during the operation when the child was hyperventilated, there existed a state of respiratory alkalosis as evidenced by low $p \mathrm{CO}_{2}$, low plasma bicarbonate, and high $\mathrm{pH}$. Following the resumption of spontaneous respiration, $p \mathrm{CO}_{2}$ levels were found to go up progressively to nelar normal figures but the plasma bicarbonate level did not, as would be expected, follow suit but remained quite low, thus leading to a significant degree of acidosis. These same workers also showed that similar changes occurred in children undergoing thoracic surgery without cardiopulmonary bypass. Adults undergoing thoracotomies also exhibited some degree of acidosis in the immediate postoperative period. ${ }^{4,5,6}$ However, it is interesting to note that postoperative acidosis in the adult is not. as marked as in children. Furthermore, it seems that in adults the plasma bicarbonate levels build up at a much faster rate in response to the rise in $p \mathrm{CO}_{2}$, thus preventing the precipitous fall in $\mathrm{pH}$ often noticed in children. This discrepancy in the clinical and laboratory findings in children and adults led us to assume that the reversible reaction $\mathrm{CO}_{2} \rightleftharpoons \mathrm{HCO}_{3}$ was, in some way, defective in children. To understand the basis of our assumption, it will be necessary to discuss the physiology of carbon dioxide transport and its role in the regulation of blood $\mathrm{pH}$.

\section{Physiology of Acid-Base Regulation}

The $\mathrm{pH}$ of the blood is regulated and maintained within a very narrow range by two mechanisms: physicochemical reactions and vital reactions.

\section{Physicochemical Reactions}

1. Role of the plasma bicarbonate in neutralizing added acids, thus:

sodium bicarbonate + lactic acid $\rightarrow$ sodium lactate + carbonic acid.

Thus the stronger fixed lactic acid is reacted upon by the alkaline reserve of the blood, changing it to a weaker volatile acid (carbonic acid).

2. Transport of carbon dioxide to the lungs in non-acid form: $\mathrm{CO}_{2}$ resulting 
from tissue metabolic processes or from the neutralization of fixed acids with plasma bicarbonate reacts to a certain extent with water in the plasma, nonenzymatically, to produce carbonic acid. Though this acid is a weak one, and though its production in the plasma is very restricted because of the lack of a catalytic enzyme, the fact still remains that if allowed to build up it can lead to marked acidosis. This explains the necessity of. carrying the main bulk of $\mathrm{CO}_{2}$ in some form other than carbonic acid. At the $\mathrm{pH}$ of the blood, carbamino compounds and bicarbonate are nonacid substances and represent the major part of carbon dioxide transport. The transport of a large proportion of the carbon dioxide load in the blood in the form of bicarbonate has the added advantage of replenishing the alkali reserve of the plasma, thus tending to minimize the changes in $\mathrm{pH}$ in the venous blood. The mechanism of bicarbonate formation is illustrated in Figure 1

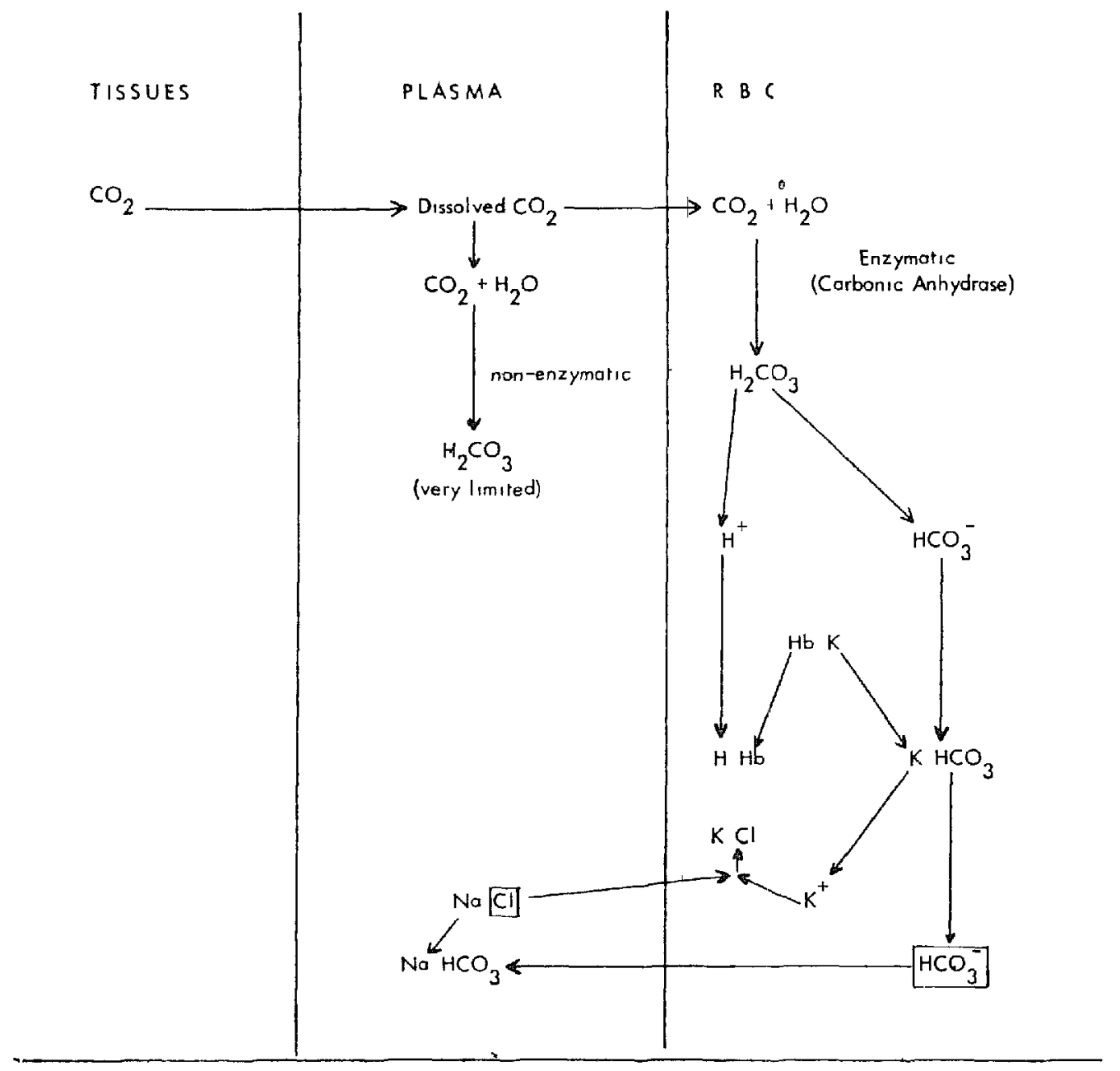

FigUre 1

\section{Vital Reactions}

1. Respiratory function. Excretion of $\mathrm{CO}_{2}$ in the lungs is largely dependent on the adequacy of ventilation. Depression of respiration leads to accumulation of $\mathrm{CO}_{2}$ and acidosis, while stimulation of breathing or hyperventilation leads to 
washing out of $\mathrm{CO}_{2}$ and alkalosis. Conversely, a rise in $p \mathrm{CO}_{2}$ leads to stimulation of respiration, while a lowering of $p \mathrm{CO}_{2}$ leads to depression of respiration.

2. Renal function. The kidneys play an important role in the regulation of the acid-base balance of the blood. This is achieved through the phosphate mechanism, the ammonia mechanism, and cation exchange in the renal tubules. However, the kidneys require a longer latent period to react to $\mathrm{pH}$ upset than does respiration.

The process that interests us in this study is the carbon dioxide-bicarbonate exchange. Interference with this exchange process can theoretically occur at the following points (Fig. 1).

1. Diffusion of $\mathrm{CO}_{2}$ through the red cell membrane. This was considered to be a possibility after it was found that the red cell membrane constituted a definite barrier to the diffusion of oxygen. ${ }^{\top}$ However, as carbon dioxide is a much more diffusable gas than oxygen, and as $\mathrm{CO}_{2}$ permeation is, probably, still faster than the chloride-bicarbonate exchange, it does not seem likely that the resistance of the red cell membrane can be rate-limiting."

2. Exchange of chloride and bicarbonate. This is the so-called chloride shift. Though this process is rapid it is by no means instantaneous, and it was estimated that in Ox blood this exchange is 90 per cent completed in 1.3 seconds. This can probably be rate-limiting if the carbonic anhydrase activity in the red cells is adequate to keep well ahead of the chloride shift. ${ }^{8.9}$

3. Carbonic anhydrase activity. It is quite possible that this important enzyme represents the weak link in the process of interconversion of carbon dioxide and bicarbonate. This enzyme has many proved potent inhibitors, such as some of the sulphonamide group of drugs, of which acetazolamide. is an example. Of more significance to the anaesthetist, however, is the fact that certain anaesthetic agents have been found to, inhibit carbonic anhydrase to a certain extent. ${ }^{10,11}$ On the other hand, determinations of carbonic anhydrase levels in haemolyzed human blood showed that the enzyme exists in amounts sufficient to accelerate the interconversion of carbon dioxide and carbonic acid some 7500 times. ${ }^{2}$.However, there is some question as to whether the enzyme is still as potent when it is confined to the red blood cells. It seems rather unlikely that the degree of inhibition caused by some anaesthetic agents as reported by Levi and Roaro ${ }^{10}$ and by Christian and Green ${ }^{11}$ can be of important physiological 'significance under ordinary circumstances.

\section{PuRpose OF THE STUdY}

The main purpose of this ${ }^{\circ}$ work is to investigate the presence of such age differences in the levels of carbonic anhydrase that could explain why children develop such profound acidosis after thoracotomies.

A fair number of papers have been published by various authors ${ }^{12-17}$ dealing with the blood levels of the enzyme in different, age groups. However, we felt that a repetition of such a study using different techniques could prove very useful in confirming previous results, and in forming a basis for fürther studies on in vitro and in vivo effects of apaesthetics on blood carbonic anhydrase. 


\section{METHOD}

In this study, blood carbonic anhydrase activity was estimated by a modification of a previously described method. ${ }^{18}$ The modification consisted of using ${ }^{\circ}$ Radiometer $\mathrm{pH}$ Meter, type PHM 22 for the measurement of $\mathrm{pH}$ changes, instead of the dye used in the original method, thus obviating the possibility of the dye interfering with the activity of the enzyme. Venous blood samples were collected, from the various subjects, in test tubes containing a very small amount of an anticoagulant salt (ethylenedinitrilo-tetra acetic acid dipotassium salt). These tubes were then immersed in chipped ice until processed.

\section{Procedure and Results}

The subjects were divided into four groups according to age.

Group 1: 20 to 45 years of age. Twenty-six normal healthy volunteers supplied the samples of blood. Three samples were taken from each subject over a period of one to two months to detect any individual variations. Altogether, seventy-five samples were collected, and their carbonic anhydrase activity assessed. The

TABLE I

Carbonic Anhydrase Activity in Adults (Age Group 20-45 Years)

\begin{tabular}{|c|c|c|c|c|c|}
\hline Subject & C.A. activity & Subject & C.A. activity & Subject & C.A. activity \\
\hline 1 & $\begin{array}{l}639 \\
541 \\
600\end{array}$ & 10 & $\begin{array}{l}588 \\
607 \\
625\end{array}$ & 19 & $\begin{array}{l}553 \\
585 \\
573\end{array}$ \\
\hline 2 & $\begin{array}{l}575 \\
608 \\
550\end{array}$ & 11 & $\begin{array}{l}621 \\
627 \\
578\end{array}$ & 20 & $\begin{array}{l}527 \\
555 \\
675\end{array}$ \\
\hline 3 & $\begin{array}{l}548 \\
592 \\
577\end{array}$ & 12 & $\begin{array}{l}625 \\
595 \\
622\end{array}$ & 21. & $\begin{array}{l}672 \\
720\end{array}$ \\
\hline 4 & $\begin{array}{l}557 \\
527 \\
588\end{array}$ & 13 & $\begin{array}{l}619 \\
628 \\
597\end{array}$ & $\begin{array}{l}22 \\
23\end{array}$ & $\begin{array}{l}630 \\
610 \\
673 \\
643\end{array}$ \\
\hline 5 & $\begin{array}{l}580 \\
518 \\
615\end{array}$ & 14 & $\begin{array}{l}785 \\
613 \\
687\end{array}$ & 24 & $\begin{array}{l}735 \\
596 \\
665\end{array}$ \\
\hline 6 & $\begin{array}{l}594 \\
580 \\
617\end{array}$ & 15 & $\begin{array}{l}522 \\
608 \\
677\end{array}$ & 25 & $\begin{array}{l}583 \\
590 \\
643\end{array}$ \\
\hline 7 & $\begin{array}{l}532 \\
514 \\
660\end{array}$ & 16 & $\begin{array}{l}602 \\
699 \\
794\end{array}$ & 26 & $\begin{array}{l}860 \\
865 \\
679\end{array}$ \\
\hline 8 & $\begin{array}{l}576 \\
639 \\
603\end{array}$ & 17 & $\begin{array}{l}587 \\
523 \\
556\end{array}$ & & \\
\hline 9 & $\begin{array}{l}543 \\
513 \\
537\end{array}$ & 18 & $\begin{array}{l}605 \\
572 \\
657\end{array}$ & & \\
\hline
\end{tabular}


results are shown in Table I. The mean value of the results is 612 carbonic anhydrase units per ml. with a standard deviation of \pm 70 .

Group 2: 60 to 90 years of age. Six samples of blood were collected from six patients in the hospital, one sample from each. Every effort was made to ensure that these patients were as normal as possible, had no organic disease, and were receiving no medications. The results are reported in Table II. The mean is 627 units with a standard deviation of \pm 67 .

TABLE II

Carbonic Anhydrase Activity in Adults (Age Group 60-90 YEARS)

\begin{tabular}{cc||cc}
\hline Subject & C A. actıity & Subject & C.A. dctivity \\
\hline 1 (70 years) & 682 & 4 (82 years) & 730 \\
2 (60 years) & 587 & 5 (74 y ears) & 571 \\
3 (90 years) & 563 & 6 (82 years) & 628 \\
\hline
\end{tabular}

TABLE III

Carbonic Anhydrase Activity in Children (Acording to Age)

\begin{tabular}{|c|c|c|c|c|c|}
\hline Subject & Age & C A activity & Subject & Age & C A. actıvity \\
\hline 1 & 14 days & 273 & 39 & 6 & 482 \\
\hline 2 & 5 months & 275 & 40 & 6 & 487 \\
\hline 3 & 5 months & 330 & 41 & 6 & 481 \\
\hline 4 & 6 months & 339 & 42 & 6 & 559 \\
\hline 5 & 8 months & 317 & 43 & 6 & 479 \\
\hline 6 & 8 months & 391 & 4.4 & 65 & 527 \\
\hline 7 & 21 months & 380 & 45 & 75 & 494 \\
\hline 8 & 21 months & 467 & 46 & 75 & 530 \\
\hline 9 & 21 months & 558 & 47 & 8 & 575 \\
\hline 10 & 2 & 527 & 48 & 8 & 469 \\
\hline 11 & 2 & 519 & 49 & 8 & 510 \\
\hline 12 & 25 & 552 & 50 . & 85 & 509 \\
\hline 13 & 25 & 459 & 51 & 85 & 582 \\
\hline 14 & 25 & 508 & 52 & 9 & 558 \\
\hline 15 & 3 & 493 & 53 & 9 & 519 \\
\hline 16 & 3 & 557 & 54 & 9 & 637 \\
\hline 17 & 3 & 494 & 55 & 9 & 467 \\
\hline 18 & 3 & 423 & 56 & 9 & 602 \\
\hline 19 & 3 & 424 & 57 & 95 & 561 \\
\hline 20 & 35 & 433 & 58 & 95 & 534 \\
\hline 21 & 35 & 378 & 59 & 10 & 526 \\
\hline 22 & 35 & 532 & 60 & 10 & 528 \\
\hline 23 & 4 & 474 & 61 & 11 & 457 \\
\hline 24 & 4 & 532 & 62 & 11 & 416 \\
\hline 25 & 45 & 501 & 63 & 11 & 518 \\
\hline 26 & 45 & 521 & 64 & 11 & 494 \\
\hline 27 & 45 & 545 & 65 & 11 & 434 \\
\hline 28 & 45 & 447 & 66 & 11 & 444 \\
\hline 29 & 5 & 532 & 67 & 11 & 494 \\
\hline 30 & 5 & 516 & 68 & 11 & 467 \\
\hline 31 & 5 & 407 & 69 & 12 & 452 \\
\hline 32 & 5 & 457 & 70 & 12 & 594 \\
\hline 33 & 5 & 315 & 71 & 125 & 531 \\
\hline 34 & 55 & 457 & 72 & 13 & 677 \\
\hline 35 & 55 & 568 & 73 & 13 & 547 \\
\hline 36 & 55 & 462 & 74 & 13 & 502 \\
\hline 37 & 55 & 513 & 75 & 14 & 607 \\
\hline 38 & 6 & 558 & 76 & 14 & 574 \\
\hline
\end{tabular}


Group 3: 14 days to 14 years of age. Over a hundred samples were collected from babies and children in the children's ward of the hospital. However, a number of these samples had to be discarded to exclude all subjects who had some organic disease or who were getting some type of medication. Seventy-six subjects ultimately supplied the samples included in this study. These were the subjects considered to be as normal as possible as they were admitted to the hospital mainly for some ophthalmological, orthopaedic, or otolaryngological procedure. The results, depicted in Table III, show the carbonic anhydrase activity according to age. Figure 2 gives a graphical presentation of these results.

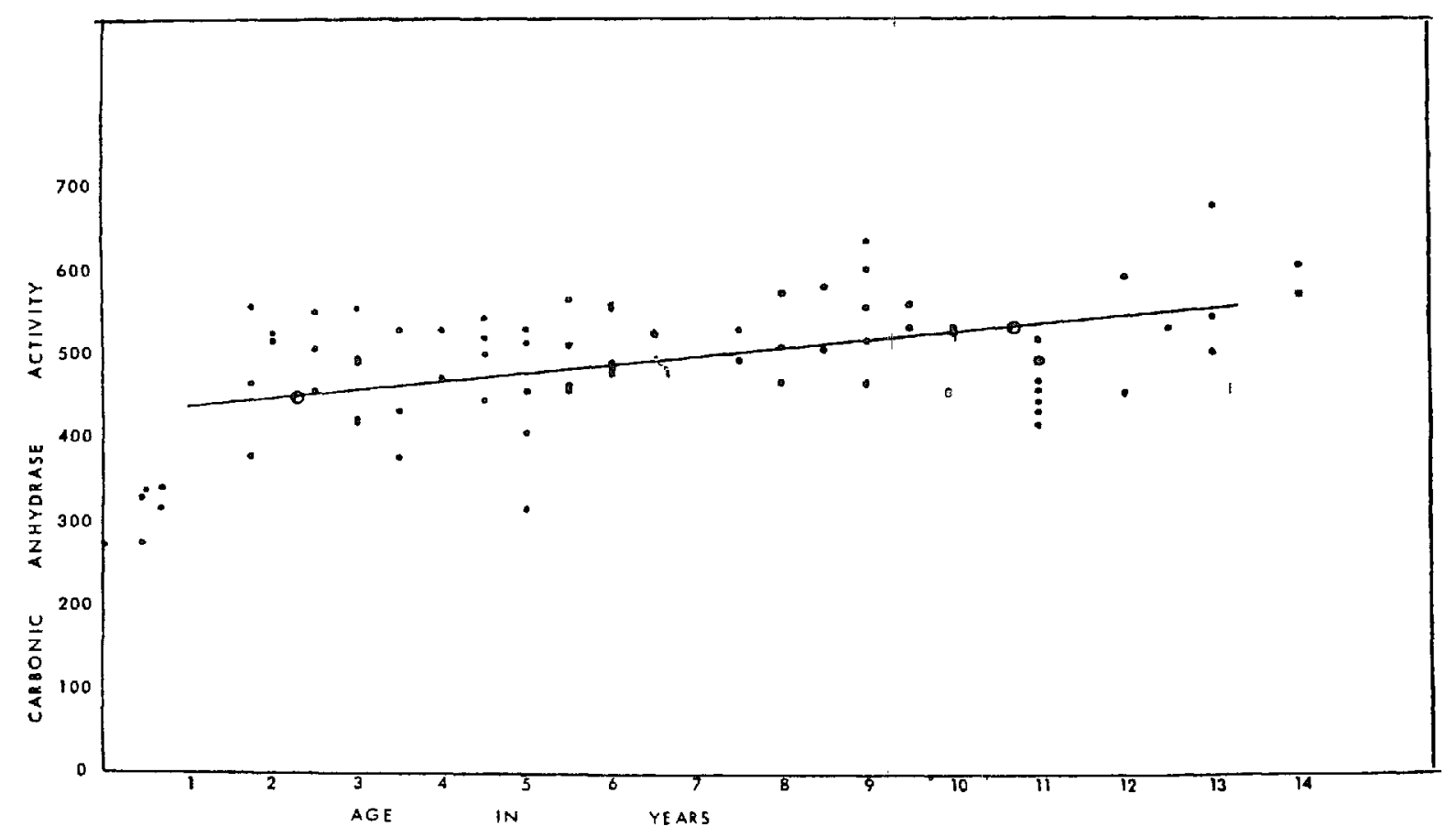

Figure 2. Scatter graph showing relationship between the ages of 76 children and their blood levels of carbonic anhydrase activity. Regression line calculated by usual statistical procedures. ${ }^{31}$

Group 4: Newborns. Samples of blood were collected from the umbilical cords of 13 neonates. All the babies were full term and all but one were delivered vaginally. Subject number 8 was delivered by Caesarian section. All mothers of vaginally delivered babies, except one, were given trichlorethylene analgesia for the relief of pain. The mother of subject number 5 had regional analgesia. The results are shown in Table IV. The mean value of carbonic anhydrase in this group is 103 , with a standard deviation of \pm 36 .

\section{Discussion}

Results obtained in this study show that newborn infants have significantly low carbonic anhydrase activity in comparison with adult levels. There is a fairly abrupt increase in activity over the first year of extrauterine, life. Our results point to a slow progressive increase after the first year until the adult levels are reached. Other workers in this field ${ }^{14,16,17}$ have reached comparable 
TABLE IV

Carbonic Anhydrase Activity (Newborn Infants)

\begin{tabular}{cc||cc}
\hline \hline Subject & C.A. activity & Subject & C.A. activity \\
\hline $\mathbf{1}$ & 159 & 8 & 38 \\
2 & $\mathbf{9 7}$ & 9 & 84 \\
3 & 99 & 10 & 86 \\
4 & 127 & 11 & 92 \\
5 & 77 & 12 & 124 \\
6 & 166 & 13 & 125 \\
7 & 66 & & \\
\hline
\end{tabular}

conclusions. Berfenstam ${ }^{15}$ in 1952 , though using a larger series and a different technique, had quite similar results. However, we found that newborn levels were about one-sixth of the adult levels, whereas in Berfenstam's series it was shown that the ratio was of the order of one-third. Similar results were also mentioned by Cutillo. ${ }^{17}$ The discrepancy between our results and those of Berfenstam and Cutillo is probably due to difference in technique, though we cannot rule out the possibility that the trilene analgesia to the mother depressed the neonatal carbonic anhydrase to a certain extent.

Carbonic anhydrase activity in premature infants was investigated thoroughly by Stevenson in 1942 and Berfenstam in 1952. Both workers showed that the level of activity decreases with increasing prematurity, so much so that in Stevenson's series some premature babies had no measurable levels of carbonic anhydrase in their blood. One of the interesting points was that blood carbonic anhydrase levels in full-term babies with very low weights at birth were quite normal, despite the fact that some of these babies weighed less than some premature babies whose enzymatic activity was very low. Berfenstam thus concluded that it is not the weight at birth as much as the degree of prematurity that decides the level of carbonic anhydrase in the blood, and that these levels are good criterion of the degree of maturity.

It can thus be said with certainty that carbonic anhydrase levels in the blood are extremely low during intrauterine life, and that they increase steadily during the latter part of foetal life until birth. Thereafter, the blood levels increase sharply during the first year of extrauterine life, and then gradually to adult levels.

The mechanisms responsible for this phenomenon have been the subject of intensive studies by Cutillo, ${ }^{17}$ who postulated that the level of carbonic anhydrase in the blood is closely related to the presence in the foetal blood of foetal haemoglobin and that as this is replaced by adult-type haemoglobin, the level of the enzyme increases proportionally until about the fourth month of extrauterine life when all traces of foetal haemoglobin disappear, and the carbonic anhydrase reaches nearly adult levels. He stated also that, occasionally, foetal haemoglobin persists beyond the early months of life into childhood or even adulthood.

\section{Clinigal Significance}

The unloading of carbon dioxide in the lungs is dependent on three major factors: (1) ventilation; (2) blood flow to the lungs, which is dependent on the 
cardiac output; (3) normal transport mechanism in the blood, dependent on carbonic anhydrase activity. When one of these factors is suppressed, normal $\mathrm{CO}_{2}$ unloading can only be achieved by an augmentation of either or both the other two.

Experimental inhibition of carbonic anhydrase activity in dogs, with the use of acetazolamide, ${ }^{19}$ produced definite impairment of carbon dioxide elimination by interfering with the transport mechanism. The degree of carbon dioxide retention was found to be dependent on associated changes in ventilation and blood flow. Hyperventilation or an increase in cardiac output tended to make up for the impairment in the carbon dioxide transport, while hypoventilation or a decrease in the blood flow produced further retention. Mithoefer's explanation of the mechanisms involved was as follows. Carbon dioxide production by the cells continues at the normal rate, despite the inhibition of the enzyme by acetazolamide. This carbon dioxide is then delivered to the venous blood as dissolved gas. However, because of the absence, or marked depression, of the enzyme in the venous blood, $\mathrm{CO}_{2}$ is not converted rapidly, to bicarbonate, thus leading to a rise in the $\mathrm{CO}_{2}$ tension in the blood and the tissues. In the blood, this increased $p \mathrm{CO}_{2}$ will probably lead to slow noncatalysed.formation of more bicarbonate, but equilibrium cannot be reached in the short time available before the blood reaches the lungs, where the excess $\mathrm{CO}_{2}$ will be eliminated. As the amount of $\mathrm{CO}_{2}$ transported in the dissolved form is limited by the solubility coefficient of the gas in plasma, and is thus very small compared to the transport capacity of the bicarbonate system, carbon dioxide elimination will be diminished. In the tissues, on the other hand, the nonenzymatic conversion of carbon dioxide to carbonic acid will not be restricted as in the circulating blood. Thus, more and more $\mathrm{CO}_{2}$ will be stored in the tissues. A new state of equilibrium will eventually result when a relatively higher percentage of $\mathrm{CO}_{2}$ is transported as carbamino compounds at a higher $p \mathrm{CO}_{2}$.

In the pulmonary capillaries, the lack of carbonic anhydrase activity will interfere with the dissociation of bicarbonate to $\mathrm{CO}_{2}$; thus the unloading of the fraction of $\mathrm{CO}_{2}$ that has been transported as bicarbonate will be incomplete. However, this nonenzymatic dissociation of bicarbonate will proceed unhampered while the blood is flowing in the arterial side of the circulation. This will lead to a gradual rise of the arterial $p \mathrm{CO}_{2}$ in excess of the alveolar $p \mathrm{CO}_{2},{ }^{20,21,22}$ and when this blood eventually reaches the tissues, less carbon dioxide will diffuse from these tissues to the capillary blood because of the decreased $\mathrm{CO}_{2}$ pressure gradient from tissues to blood. This will obviously lead to more carbon dioxide retention in the tissues, and increasing acidosis.

A number of workers in this field, ${ }^{16,17}$ have toyed with the possibility that very low carbonic anhydrase levels in the blood of newborn infants and very young babies might interfere in some way with their carbon dioxide elimination and $\mathrm{pH}$ regulation. However, these infants show no carbon dioxide retention nor $\mathrm{pH}$ imbalance under ordinary circumstances, despite the associated very low carbonic anhydrase levels. Furthermore, normal resting" adult volunteers given acetazolamide, to inhibit their carbonic anhydrase activity to levels lower than those found even in premature babies, failed to show any impairment of their carbon dioxide 
elimination. ${ }^{20,23}$ This discrepancy in the effects of acetazolamide in humans and dogs remains essentially unexplained.' On the other hand, these findings in humans by no means rule out the possibility of low carbonic anhydrase levels interfering with their $\mathrm{CO}_{2}$ elimination if, because of depressed ventilation or increased $\mathrm{CO}_{2}$ output or both, the load of carbon dioxide becomes relatively too much for the available enzyme. Indeed, it would be reasonable to assume that such a situation could lead to the same sequence of events as occurs in dogs whose enzyme had been inhibited by acetazolamide. Of particular interest in this respect were the findings in a number of normal adult volunteers whose carbonic anhydrase was inhibited by acetazolamide, and who were then made to do severe muscular exercise. They showed arterial-alveolar $p \mathrm{CO}_{2}$ gradients of $5-12 \mathrm{~mm}$. $\mathrm{Hg}$, and changes in the elimination of carbon dioxide which suggested that $\mathrm{CO}_{2}$ production exceeded elimination. The interesting point was that these same volunteers did not show any of the above findings when they were not exercising, despite the fact that their enzyme was inhibited.

On the basis of our findings and the foregoing discussion, we propose to submit the following explanation of the severe acidosis that occurs in newborns and very young babies, not only after thoracotomies and cardiopulmonary bypass, but also in conditions such as hyaline membrane disease and asphyxia neonatorum.

\section{Post-thoracotomy Acidosis}

Two factors are believed to be responsible for the production of post-thoracotomy acidosis.

1. Hypoventilation. It has been recognized for some time that thoracotomies are followed, in the immediate postoperative period, by definite reduction in the ventilatory.powers of the patients. Smith et al. ${ }^{6}$ reported $a_{p} 50$ per cent reduction in the vital capacity compared to preoperative levels. This reduction was observed within the first 24-48 hours postoperatively. They also found that patients undergoing operations other than thoracotamies showed an average of only 10 per cent reduction in their vital capacities, postoperatively. Martin and Stead ${ }^{24}$ and Hood and Beall ${ }^{5}$ also reported on postoperative hypoventilation. They showed that this depression of respiration was particularly noticeable during the first hour after the completion of thoracic operations, and that marked hypoventilation was seldom encountered after abdominal operations. Clowes et al., ${ }^{25}$ on the other hand, reported that when ventilation and $\mathrm{pH}$ measurements were done 3-5 hours after thoracotomies, the tidal volumes were only slightly depressed.

2. Metabolic acidosis. The occurrence of some degree of metabolic acidosis during operations and in the immediate postoperative period has seen reported innumerable timès. ${ }^{26,2 \pi, 28,29}$ Various factors have been postulated as causing this acidosis. Tissue hypoxia and increased adrenal discharge were among the most important causes mentioned. Papadopoulos and Keats ${ }^{30}$ claimed that certain tissue compensatory mechanisms teact to the marked respiratory alkalosis produced by vigorous hyperventilation by an increase in the tótal fixed acids and blood lactic acid. Whatever the cause of the acidosis, neutralization of the resulting excess of fixed acids in the blood will lead to the depletion of the existing serum bicarbonate. At the same time, carbon dioxide continues. to accumulate 
in the tissues and blood because of the depression of ventilation, thus disturbing the balance between the carbon dioxide load and the available carbonic anhydrase in the blood of the infant. The result is that less bicarbonate will be produced than would otherwise have been the case if the patient were an adult with higher carbonic anhydrase levels.

The end result of the above-mentioned disturbances will be a fairly high $p \mathrm{CO}_{2}$, quite low serum bicarbonate levels, and precipitous fall of $\mathrm{pH}$. These findings will persist until the baby's ventilation becomes less depressed, leading to the washing out of the excess carbon dioxide and the re-establishment of a more favourable ratio between the carbon dioxide load and the existing carbonic anhydrase.

\section{Hyaline Membrane Disease and Asphyxia Neonatorum}

Hyaline membrane disease is characterized by marked interference with the gaseous exchange in the lungs leading to hypoxia and accumulation of carbon dioxide. Here again the precarious balance between the carbon dioxide load and the available carbonic anhydrase will become disturbed, particularly as most of these babies are prematures whose blood levels of the enzyme are extremely low or even nomexistent. Thus, the formation of bicarbonate will be interfered with leading to a relative preponderance of carbonic "acid and acidosis. Further intensification of the acidosis will result when some of the existing bicarbonate is used up to neutralize the increasing àmount of fixed acids resulting from the associated hypoxia.

In asphyxia neonatorum, the same sequence of events results in the rapid development of dangerous levels of acidosis.

\section{Conclusions}

A given load of the potentially acid-forming carbon dioxide can be disposed of in two ways.

1. Excretion in the lungs. This is the ideal and ultimate channel for getting rid of the gas, and is dependent on adequate ventilation.

2. Transforming the gas into bicarbonate. This is a make-shift process, the purpose of which is to minimize the harmful effects of carbon dioxide by changing part of it to bicarbonate, thus checking a severe and rapid fall in the $\mathrm{pH}$ that would otherwise occur if all or most of the gas was left unchanged. This process is dependent on the presence of carbonic anhydrase in adequate amounts. in the blood.

Premature babies, newborns, and very young infants have been found to have very low-levels of blood carbonic anhydrase. This fact makes this group of individuals much more dependent on adequate ventilation than adults. We consequently propose that, because of the very low levels of the enzyme, a period of apnoea or hypoventilation in premature infants and very young babies is liablé to produce a more precipitous fall in the $\mathrm{pH}$ than would a comparable period in an adult. This makes the re-establishment of adequate ventilation in the very young a more urgent matter than in the adult.

The institution of adequate ventilation is not difficult in infants suffering from 
post-thoracotomy acidosis or from asphyxia neonatorum. In victims of hyaline membrane disease, however, assistance of respiration is of no avail, and it is quite possible that cardiopulmonary bypass may prove to be the most successful line of treatment.

\section{Summary}

1. Blood carbonic anhydrase activity was estimated in individuals belonging to four age groups. Our results show that the level of activity in adults is significantly higher than in the newborn.

2. A theory was proposed as to the clinical significance of very low carbonic anhydrase levels in premature babies, the newborn, and very young infants.

\section{ACKNOWLEDGMENT}

The authors would like to thank Mrs. Lucille Larson, R.T.; Technician, Analytical Laboratory, University of Saskatchewan, for the labboratory work entailed in this paper.

\section{RÉSUMÉ}

On peut se défaire de deux façons d'une quantité donnée de $\mathrm{CO}_{2}$ susceptible d'engendrer de l'acide:

1. En l'éliminant par les'poumons. C'est la voie idéale et définitive pour se débarrasser de ce gaz et cela dépend d'une ventilation adéquate.

2. En transformant le gaz en bicarbonate. Ceci est un processus de déviation dont le but est de réduire au minimum les effets nuisibles du $\mathrm{CO}_{2}$ en en transformant une partie en bicarbonatés, évitant ainsi une chute sérieuse et rapide du $\mathrm{pH}$ qui, autrement, surviendrait si le $\mathrm{CO}_{2}$ demeurait inchangé en tout ou en partie. Ce processus est dépendant de la présence d'anhydrase carbonique en quantité suffisante dans le sang.

Chez les prématurés, les nouveau-nés, et les enfants très jeunes, nous avons trouvé des taux très bas d'anhydrasé carbonique dans le sang. Ce fait rend ce groupe d'individus beaucoup plus vulnérables que les adultes si la ventilation n'est pas adéquate. En conséquence, nous considérons que, à cause des taux très bas d'enzymes, une période d'apnée ou d'hypoventilation, chez des prématurés ou chez des jeunes bébés, peut produire une chute plus rapide du $\mathrm{pH}$ qu'une apnée semblable ne pourrait le faire chez un adulte.

Cela impose une obligation plus urgente de rétablir une ventilation adéquate chez les tout jeunes que chez les adultes.

Chez les enfants souffrant d'acidose à la suite d'une thoracotomie ou d'asphyxie des nouveaux-nés, il n'est pas difficile de rétablir une ventilation adéquate. Toutefois, chez les porteurs de membrane hyaline, l'assistance de la respiration n'apporte aucune amélioration, mais il est bien possible que la circulation extracorporelle s'avère un des traitements les plus efficaces.

1. Nous avons calculé l'activité de l'anhydrase carbonique sanguine chez des individus répartis en quatre groupes d'âge différent. Nos résultats révèlent que le taux d'activité chez les adultes est sensiblement plus élevé que chez les nouveaux-nés. 
2. Nous avons mis de l'avant une théorie concernant la signification clinique de taux très bas d'anhydrase carbonique chez les prématurés, chez les nouveaux-nés et chez les tout jeunes enfants.

\section{REFERENCES}

1. Davis, R. P. The Enzymes, edited by P. D. Boyer, H. LARDy, and K. Myrback, 2nd ed. New York: Academic Press (1961).

2. Berliner, R. W. \& Orloff, J. Carbonic Anhydrase Inhibitors. Pharmacol. Revs. 8: 137 (1956).

3. Rougrton, F. J. W. \& Clark, A. M. Carbonic Anhydrase, The Enzymes, edited by J. B. Sumner, and K. Mrrback. New York: Academic Press (1951).

4. Dobel, A. R. C.; Gutelrus, J. R.; \& Murphy, D. Acildosis Following Respiratory Alkalosis in Thoracic Operations with and without Heart-Lung By-pass. J. Thoracic \& Cardiovasc. Surg. 39: 312 (1960).

5. Hoon, R. M. \& BEALL, A. C. Hypoventilation, Hypoxia and Acidosis Occurring in the - Acute Postoperative Period. J. Thoracic Surg. 36: 729 (1958).

6. SMith, T. C.; Cook, F. D.; DeKonNFeld, T. J; \& SiEbeCKen, K, L. Pulmonary Function in the Immediate Postoperative Period. J. Thoracic \& Cardiovasc. Surg. 39: 788 (1960).

7. Gibson, Q. H.; Kreuzen, F.; Meda, E.; \& Roughton, F. J. W. The Kinetics of Human Hemoglobin in Solution and in Red Cell at 37 C. J. Physiol, 129: 65 (1955).

8. Rougrton, F. J. W. Recent Work on Carbon Lioxide Transport by the Blood. Physiol. Revs. 15: 241 (1935).

9. Draken, M. N. J. \& Mook, H. W. The Rate of Gás Exchange between Blood Cells and Serum. J. Physiol. 73: 349 (1931).

10. Levi, E. \& Roaro, G. Modificazioni dell' attivita carbonico-anidrasica dopo induzione barbiturica. Minerva Anest. 24: 415 (1958).

11. Christian, G. \& Green, N. M. Blood Carbonic Anhydrase Activity in Anesthetized Man. Anesthesiology 23: 179 (1962).

12. Altschule, H. D. \& Lewis, M. D. Measurement of Carbonic Anhydrase Activity at Body Temperature. J. Biol. Chem. 180: 557 (1949).

13. Altschule, H. D. \& Smrth, C. A. Blood Carbonic Anhydrase in Newborn Infants and Their-Mothers. Pediatrics 6: 717 (1950).

14. Stevenson, S. S. Blood Carbonic Anhydrase in Newborn Infants. J. Clin. Invest. 22: 403 (1943).

15. Berfenstam, R. Studies on Carbonic Anhydrase Activity in Children. I. Enzyme Activity in the Blood of Infants and Children of Different Ages, Particularly in Premature Infants. Acta Pediatrica 41: 32 (1952).

16. Berfenstam, R. Studies on Carbonic Anhydrase Activity in Children. II. Possibilities of Influencing the Carbonic Anhydrase Activity in the Blood of Premature Infants. Acta Pediatrica 41: 297 (1952).

17. Cutmlo, S. L'attivita dell' anidrasi carbonica nel sangue durant il primo mese di vita. Pediatrica (Napoli) 64: 45 (1956).

18. Woodford, V. R.; Ieegwater, N.; \& Drance, S, M. A Comparative Study of Some Carbonic Anhydrase Inhibitors. Can. J. Biochem. Physiol. 39: 287 (1961).

19. Mrthoefer, J. C. Inhibition of Carbonic Anhydrase, Its Effect on Carbon Dioxide Elimination by the Lungs. J. Appl. Physiol. 14: 109 (1959).

20. Tomashefski, J. F.; ChnnN, H. I.; \& Clark, R. T. JR. 'Effect of Carbonic Anhydrase Inhibition on Respiration. Am. J. Physiol. 177: 451 (1954).

21. Canter, E. T. Regulation of Respiration during Carbonic Anhydrase Inhibition. Fed. Proc. 13: 23 (1954).

22. MAREN, T. H. Carbonic Anhydrase Inhibition: IV-The Effects of Metabolic Acidosis on the Response to Diamox. Johns Fopkins Hosp. Bull. 98: 159 (1956).

23. Shepard, R. H.; Donso, H.; Kulick, E. M.; Cherniack, R. M.; Jones, C. J.; \& Ruley, R. L. Interference with Release of $\mathrm{CO}_{2}$ from Pulmonary Capillary Blood after Inhibition of Carbonic Anhydrase. Fed. Proc. 13: 1,85 (1954).

24. Martin, F. E. \& STEAd, W. W. Physiologic Studies Following Thoracic Surgery. IIIVentilatory Studies in the Immediate Postoperative Period. J. Thoracic Surg. 25: 417 (1953).

25. Clowes, G. H. A., Jr.; Alichniewicz, A.; Del Guerico, L. R. M.; \& Gillesspie, D. The 
Relationship of Postoperative Acidosis to Pulmonary and Cardiovascular Function. J. Thoracic \& Cardiovasc. Surg. 39:1 1 (1960).

26. Leigh, M. D. Acidosis during Clinical Anesthesia. Anesthesiology 3: 429 (1942).

27. BeEcher, H. K., \& Murphy, A. J. Acidosis during Thoracic Surgery. J. Thoracic Surg. 19: $50(1950)$.

28. Tayzor, F. H. \& Roos, A. Disturbances in Acid-Base Balance during Ether Anesthesia with Special Reference to Changes Occuring during Thoracic Surgery. J. Thoracic Surg. 20: 289 (1950).

29. Bunker, J. P.; Brewster, W. R., Jr.; Smith, R. M.; \& Beecher, H. K. Metabolic Effects of Anesthesia in Man; Acid-Base Balance in Infants and Children during Anesthesia. J. Appl. Physiol. 5: 233 (1952).

30. Papadopoulos, C. N. \& Keats, A. S. Metabolic Acidosis of Hyperventilation Produced by Controlled Respiration. Anesthesiology 20: 156 (1959).

31. Snedecon, G. W. Statistical Methods, 4th ed. Ames, Iowa: The Iowa State College Press (1955). 